\title{
Characterization and Immunological Properties of Pseudomonas aeruginosa Hemolytic Phospholipase C
}

\author{
W.A.A. Hassanein \\ Department of Botany, Faculty of Science, Zagazig University, \\ Egypt.
}

\begin{abstract}
Dh OSPHOLIPASE C (PLC) produced from 4 day age culture of $P$. aeruginosa strain in inorganic phosphate starved liquid medium (pH7.2) at 35C. The enzyme was purified to electrophoretic homogeneity using gel filtration chromatography. Purified PLC had 6.2 purification fold and $28.2 \%$ yield. The purified enzyme had a molecular mass of $58.7 \mathrm{kDa}$. Alanine was the dominant amino acid with $13.1 \%$. DNA sequence analysis of the PCR products amplified from $P$. aeruginosa confirmed the presence putative $p l c \mathrm{H}$ gene $(1.6 \mathrm{~kb})$. The enzyme was completely inactive above $65 \mathrm{C}$ with $\mathrm{Tm} 42 \mathrm{C}$. The enzyme activity was approximately stable at $\mathrm{pH} 8.5$ to 10 . The purified enzyme was characterized as a $\mathrm{Zn}^{2+}$-metallophospholipase $\mathrm{C}$ and also divalent ions $\mathrm{Ca}^{2+}, \mathrm{Ba}^{2+}$ and $\mathrm{Co}^{2+}$ were stimulators for its activity. The catalytic affinity of PLC enzyme towards phosphatidylcholine (PC) gave $\mathrm{V}_{\max }=$ $1.85 \mathrm{Umg}^{-1} \mathrm{~min}^{-1} ; \mathrm{Km}=0.12 \mathrm{M}$ and Kcat $=1.96 \times 10^{-5} \mathrm{~S}^{-1}$. Purified PLC enzyme was detoxified by heating and completely lost its lethal activity on mice after $60 \mathrm{~min}$ at $65 \mathrm{C}$. Immunologically, the titer of IgG antibodies in blood serum of New Zealand rabbits was appeared after 15 days of the last injection dose of fresh or heat detoxified enzyme by 1.15 and 1.21 fold respectively higher as compared to control followed by a decrease in the titer up to 45 days. The hematological parameters reflected a decrease in the RBCs, WBCs and hemoglobin in rabbits injected with fresh enzyme and there was significant change in chemistry of liver and kidney. In contrarily detoxified enzyme had no obvious changes in these parameters.
\end{abstract}

Keywords: Pseudomonas aeruginosa; Phospholipase C, Antigenicity, Cytotoxicity

Phospholipases have a wide spectrum of in vivo and in vitro effects, ranging from minor alterations in cell membrane composition and function to lethality. The most important classes of phospholipases that have been shown to play a significant role in bacterial pathogenesis are phospholipase $\mathrm{C}$ and phospholipase D (Schmiel and Miller, 1999). Pseudomonas aeruginosa derived large extracellular protease (LepA) and hemolytic phospholipase C (PLCH) which were considered to play an important role in the pathogenicity of this organism (Kida et al., 2011).

Corresponding author: Wesam A. Hassanien (wesamtarek2@yahoo.com) 01060242448 
Two known phopholipases $\mathrm{C}$ were elaborated from $P$. aeruginosa, hemolytic (PLCH) and non-hemolytic (PLCN). The PLCH may be an important virulence factor. Indeed, purified PLCH causes vascular permeability, end organ damage, and death when injected into mice in high doses (Meyers et al., 1992 and Wargo et al., 2011). These hemolytic enzymes are cytolytic toxic proteins produced by wide range of bacteria causing lyses of erythrocytes, disrupting the function of the plasma membrane (Magalhaes et al., 2011).

Phospholipase $\mathrm{C}$ is a heat labile hemolysin produced by $P$. aeruginosa (Stonehouse et al., 2002).This PLCH catalyzes the hydrolysis of phosphatidylcholine (PC) yielding phosphorylcholine and diacylglycerol (DAG) (Flieger et al., 2000). The production of DAG may be particularly important in pathogenesis causing eukaryotic signaling events (Titball, 1998).

The phospholipase $\mathrm{C}(\mathrm{plc})$ gene of $P$. aeruginosa encodes a heat-labile secreted hemolysin which is part of a Pi-regulated operon (Ostroff and Vasil, 1987). Pseudomonas aeruginosa $p l c \mathrm{H}$ and $p l c \mathrm{~N}$ genes are encoding for the hemolytic and nonhemolytic phospholipase C enzymes (Gomez et al., 2001). In the lung of cystic fibrosis (CF) patient, $P$. aeruginosa induced $p l c \mathrm{H}$ and genes involved in both choline diacyglycerol catabolism, which supports the hypothesis that PLCH enzyme is important for colonization of the lung (Son et al., 2007). The PLCH-mediated degradation of the PC in lung surfactant contributes to lung infection (Wargo et al., 2009).

Hemolytic PLC had been demonstrated to be a virulence determinant of $P$. aeruginosa in a variety of infection models in mammals (Chin and Watts, 1988).The immunological characteristics of hemolytic PLC attracted the attention of many investigators due to their importance (Meyers et al., 1992; Estahbanati et al., 2002 and Ipaktchi et al., 2007).Applications on animal protection using heat detoxified toxins were previously studied by Manohar et al. (1966) and Khalil (2009).

In the light of the previous facts the objective of current study was the production, purification and characterization of PLC from tested $P$. aeruginosa. Investigation for biochemical and molecular properties, kinetics and hemolytic activity of the pure enzyme. Assessment for antigenecity and toxicity of the tested enzyme, in vivo, in animal models.

\section{Material and Methods}

\section{Bacterial strain and PLC production:}

Pseudomonas aeruginosa (1589741) was obtained from the previous work of Hassanein (2009). Phosphate starved Tris minimal medium (TMM) was used in which the concentration of the phosphate $\left(\mathrm{KH}_{2} \mathrm{PO}_{4}\right)$ was recorded to be $0.1 \mathrm{mM}$. The TMM had the composition: $100 \mathrm{mM}$ tris- $\mathrm{HCl}(\mathrm{pH} 7.2), 11 \mathrm{mM}$, glucose, 5 $\mathrm{mM} \mathrm{NH}_{4} \mathrm{Cl}, 10 \mathrm{mM} \mathrm{KH}_{2} \mathrm{PO}_{4}, 0.5 \mathrm{mM} \mathrm{K}_{2} \mathrm{SO}_{4}, 0.1 \mathrm{mM} \mathrm{CaCl}, 10 \mathrm{mM} \mathrm{MgCl}$ as 
reported by Elleboudy et al. (2011). After incubation for 4 days at 35C and centrifugation for $15 \mathrm{~min}$ at $6000 \mathrm{rpm}$, the supernatant was used as crude enzyme.

\section{Purification of phospholipase C}

The crude PLC extracted from $P$. aeruginosa growing in PLC production medium under cultural conditions was fractionated by ammonium sulfate of $70 \%$ saturation. The precipitated proteins were dissolved and then dialysed against 10 $\mathrm{mM}$ Tris $\mathrm{HCl}$ buffer ( $\mathrm{pH}$ 7.2) (Ostroff and Vasil, 1987). Gel filtration using Sephadex G100 was used as described by Berk (1964). The active fractions were pooled and concentrated by dialysis against polyethylene glycol. For each fraction protein content and PLC activity were determined.

\section{Phospholipase $C$ activity}

The activity of PLC was assayed according to Kurioka and Liu (1967). Egg yolk L--phosphatidylcholine (PC) obtained from Sigma Chemical Co.(St. Louis, Mo.USA) was used as substrate. Colloidal solution of PC was prepared by adding $25 \mathrm{mM}$ of $\mathrm{PC}$ suspension in $0.25 \mathrm{M}$ tris $\mathrm{HCl}$ buffer $\mathrm{pH}$ 7.2. A homogenous suspension was achieved using a mixer for 10 min at $4 \mathrm{C}$,

The basal reaction mixture for the assay consisted of $0.1 \mathrm{ml}$ of the PLC, 0.4 $\mathrm{ml}$ of the PC solution and $0.5 \mathrm{ml}$ of $0.25 \mathrm{M}$ Tris $\mathrm{HCl}$ buffer $(\mathrm{pH} \mathrm{7.2).} \mathrm{After}$ incubation at $37 \mathrm{C}$ for $30 \mathrm{~min}$, the enzymatic reaction was stopped by $1.0 \mathrm{ml}$ of $10 \%$ trichloroacetic acid. After centrifugation a portion of the supernatant fluid $(1.0 \mathrm{ml})$ was digested and the inorganic phosphate content was determined according to Kates (1972). One unit of PLC activity was defined as the amount of enzyme which releases $1 \mu \mathrm{mol}$ of pi (inorganic phosphorus) under standard assay conditions. The enzyme protein was determined by method of Lowry et al. (1951), using bovine serum albumin as a standard. Hemolytic activity of PLC was determined by agar well diffusion method as described by Mukry et al. (2010).

\section{SDS-PAGE analysis}

Molecular weight of PLC was determined according to the method of Laemmli (1970) using SDS-polyacrylamide gel electrophoresis. Multicolor Broad range protein ladder has 4-color protein standards with 10 recombinant proteins covering a molecular weight from 10 to $260 \mathrm{KDa}$ was used.

Amino acids analysis

Amino acid composition of PLC was determined according to the method used by Tous et al. (1989) applying the GLC hydrolytic technique with a Beckman amino acids analyzer ( SYKAMS7130 Amino acid Reagan Organizer) 


\section{Detection of plcH gene}

a-Preparation of DNA

The DNA was extracted from $P$. aeruginosa growing in PLC production medium according to Sambrook and Russel (2001).

\section{b-Polymerase Chain Reaction (PCR)}

Polymerase Chain Reaction (PCR) was used to amplify $p l c \mathrm{H}$ gene from $P$. aeruginose. The PCR amplifications were performed in a total volume of 501 containing $25 \mu \mathrm{l}$ of PCR Master Mix. (2x), $0.5 \mu \mathrm{l}$ of Taq polymerase $25 \mathrm{pmol}$ of both primers (forward primer 5'- ATG TCA GGC ATG CAA ACC CCG C-3'; reverse primer 5'-TCA CGC GTT GCG GTC GAT GTA G-3') and template DNA (100 ng). The reaction mixtures were covered with mineral oil and PCR amplification was carried out in a Gene-Amp PCR system 9600 thermocycler (Perkin Elmer). The amplification conditions were as follows: $94^{\circ} \mathrm{C}$ for $10 \mathrm{~min}$ and 35 cycles of denaturation at $95^{\circ} \mathrm{C}$ for $30 \mathrm{~s}$, annealing-extension at $56^{\circ} \mathrm{C}$ for $30 \mathrm{~s}, 72^{\circ} \mathrm{C}$ for $1 \mathrm{~min}$., $72^{\circ} \mathrm{C}$ for $10 \mathrm{~min}$. and final hold program at $4^{\circ} \mathrm{C}$.

\section{c-Agarose gel electrophoresis}

The PCR product was detected by $(1 \%)$ agarose supplied from gel electrophoresis at $50 \mathrm{~V}$ for 1 in $1 \mathrm{x}$ Tris- Boric acid -EDTA (lx TBE) buffer. Ethidium bromide for staining and UV transillumination were used. Then PCR clean up to the PCR product was made up using Gene JET ${ }^{\mathrm{TM}}$ PCR purification kit (fermentas). Finally sequencing to the PCR product was carry on GATC German Company by ABI 3730XI DNA sequencer using the forward and reverse primers. The resulting DNA sequences were compared using the Basic Local Alignment Search Tool (BLAST) program (Altschul et al., 1997).

\section{Biochemical properties of phospholipase $C$}

The thermal stability of PLC was studied after preincubation of the enzyme at various temperature (25-80C) using $10 \mathrm{mM}$ Tris $\mathrm{HCl}$ buffer $(\mathrm{pH} 7.2)$ for different time (30-150 min). The substrate PC $(1.5 \mathrm{M})$ was added to the enzyme. The enzyme relative activity was determined after the incubation of reaction mixture at $37 \mathrm{C}$ for $30 \mathrm{~min}$. The thermal inactivation rate $(\mathrm{Kr} \min )$ can be described by the first-order kinetic model (Whitaker, 1972); $\operatorname{Ln}\left(\mathrm{A}_{t} / \mathrm{A}_{o}\right) \mathrm{k}_{\mathrm{t}} \mathrm{T}$, where $A_{o}$ and $A_{t}$ are the specific activity at zero and time. The T1/2 (time at which the enzyme loss $50 \%$ of its activity) was calculated from the linear equation for each temperature. The temperature at which the enzyme loss $50 \%$ of its activity (Tm) was calculated from the linear equation of different preincubation temperature at $60 \mathrm{~min}$.

Stability of PLC was examined after preincubation of the enzyme for $30 \mathrm{~min}$ at different $\mathrm{pH}$ values ranging from $4-11$. Acetate $(0.2 \mathrm{M})$, phosphate $(0.2 \mathrm{M})$ and glycine- $\mathrm{NaOH}$ buffers were used to achieve $\mathrm{pH}$ range (4-5), (6-8) and (9-11) respectively. After adding PC $(1.5 \mathrm{M})$ the reaction mixture was incubated at $37 \mathrm{C}$ for $30 \mathrm{~min}$. The activity of the enzyme was determined for each $\mathrm{pH}$. 
To assay the metal ions effect, the purified PLC was preincubated in $0.1 \mathrm{mM}$ EDTA at $4 \mathrm{C}$ for $2 \mathrm{hr}$, and then dialyzed against $10 \mathrm{mM}$ Tris- $\mathrm{HCl}$ (pH 7.2). The enzyme was incubated with each metal ion separately for 30 min before adding PC $(1.5 \mathrm{M})$. Metal ions in form of $\mathrm{MnSO}_{4}, \mathrm{MgSO}_{4}, \mathrm{ZnCl}_{2}, \mathrm{CaCO}_{3}, \mathrm{CoCl}_{2}$, $\mathrm{CuSO}_{4}, \mathrm{FeSO}_{4}$ and $\mathrm{BaCl}_{2}(5 \mathrm{mM})$ as well as EDTA $(1$ and $5 \mathrm{mM})$ were used. The enzyme relative activity was determined immediately after incubation at $37 \mathrm{C}$ for $30 \mathrm{~min}$.

The kinetic parameters of PLC as Vmax, Km and Kcat were estimated using different concentrations of egg yolk PC (0.1-1.5 M). Michaelis-Mentel constant $(\mathrm{Km})$ and maximum velocity (Vmax) were calculated from Lineweaver-Burk plot. Catalytic efficiency (Kcat) was expressed by the specific activity per mol enzyme.

\section{Heat detoxification of PLC}

According to the data obtained from the thermal kinetics, the pure enzyme was heat detoxified in water bath for 30,60 and $90 \mathrm{~min}$ at $65 \mathrm{C}$ in $0.25 \mathrm{mM}$ Tris $\mathrm{HCl}$ buffer $(\mathrm{pH}$ 7.2).Then the enzyme was immediately placed in an ice bath (Manohar et al., 1966) .The hemolytic titer and mice mortality were then measured.

\section{Hemolytic titer of PLC}

According to Johnson and Boese-Marazzo (1980) hemolytic titer of PLC was determined by two fold dilutions in buffered saline ( $\mathrm{pH} 5.9$ ); and $0.5 \mathrm{ml}$ of $1 \%$ suspension of prewashed red cells was added. After $1 \mathrm{hr}$ incubation at 37C, the dilution showing complete hemolysis was taken as an endpoint, the reciprocal of this number was used as the titer (hemolytic unit HU/ml).

\section{Animal mortality by P. aeruginosa PLC}

Different groups of four male Swiss albino mice (6-8 weeks old) were intraperitoneally (i.p.) injected by $1 \mathrm{ml}$ of hemolytic titer of fresh and heat detoxified $P$. aeruginosa PLC (64 and $32 \mathrm{HU} / \mathrm{ml} / \mathrm{mice}$ respectively) . Control animal groups were challenged with buffered saline ( $\mathrm{pH}$ 5.9). Mortality within $12 \mathrm{hr}$ was considered to be due to toxin (Manohar et al., 1966). The mortality level was measured as number of dead mice/total number of mice per group (Abraham, 1992).

\section{Anti-PLC antibodies}

The New Zealand rabbits were used for this experiment .Different groups of four male animal were intravenous (i.v.) injected by $1 \mathrm{ml}$ of three successive doses of hemolytic titer of normal and detoxified PLC (64 and 32 $\mathrm{HU} / \mathrm{ml} / 1.5 \pm 0.1 \mathrm{Kg}$ body weight respectively) during two weeks. Control animal groups were challenged with buffered saline $(\mathrm{pH}$ 5.9). Blood samples were collected from the rabbits after 7, 15, 22, 30, 37 and 45 days of the last PLC injection. Control sera (zero time) without enzyme injection were used. Plasma were prepared and stored at $-20^{\circ} \mathrm{C}$. PLC immunoglobulin class antibodies were 
measured by the Radial Immunodiffusion (RID) plate assays Kit, DIFFUPLATE (Biocientifica S.A., Buenos Aires, Argentina). DIFFU-PLATE for IgG was applied. According to the protocol, $5 \mu \mathrm{l}$ of blood plasma was injected to the well of the plate (12 well per plate), and incubated at room temperature for $24 \mathrm{hr}$. The diameter of sharp antigen antibodies precipitation layer was measured using the magnifying glass with accurate special ruler. The precipitation ring was calibrated from the reference table of the RID Kit, for estimation of immunoglobulins titer ( $\operatorname{IgG})$ comparing to control sera.

\section{Blood Biochemistry of rabbits harboring PLC}

From the last experiments biological effects of normal and detoxified PLC on blood chemistry of treated rabbits, various hematological and biochemical parameters were determined. The hematological parameters as red blood corpuscles (RBCs), white blood corpuscles (WBCs), hemoglobin, were analyzed (Erma INC automated hematology analyzer). As well as, the biochemical parameters of liver function ( ALK, AST, ALT, total protein, albumin and BIL) and kidney function ( urea and creatinine) were assessed by automated chemistry analyzer (Dimension RXL Autoanalyzer). Control groups were considered at zero time.

\section{Statistic analysis}

All data were the mean of three replicates SD standard deviation (SD). Different values within the same column differ significantly at $\mathrm{P}<0.01$. The data were analyzed by one-way ANOVA (Salvatore and Reagle, 2001). Less significant difference was calculated

\section{Results and Discussion}

\section{Purification of $P$. aeruginosa PLC}

Phospholipase $\mathrm{C}$ was purified as an extracellular enzyme from the liquid cultures of 4-day age of $P$. aeruginosa growing in TMM broth medium ( $\mathrm{pH} 7$ ) using $70 \%\left(\mathrm{NH}_{4}\right)_{2} \mathrm{SO}_{4}$. From the purification profile of tested PLC a sharp peak containing the active PLC was found in fractions no. 16 to 19 (data not shown). The specific activity of PLC was $118.7 \mathrm{U} \mathrm{mg}^{-1}$ protein compared to $19 \mathrm{U} \mathrm{mg}^{-1}$ crude protein. Also the purification achieved 6.2 fold and $28.2 \%$ yield by sephadex-G100 of purified enzyme (Table 1). In a similar manner Crevel et al. (1994) reported that after gel filtration purity of PLC from P. fluorescens increased to 32.6 folds . Also PLC from Bacillus mycoides showed 40.8 folds increase in purity assuming that filtration step is the key to the homogeneity, as PLC is easy to polymerize with other impurities (Wang et al., 2010).

In the present study, the homogeneity and molecular mass of the purified PLC (Fig. 1) appeared as a single protein band of $58.7 \mathrm{kDa}$, assuming the potency of the purification protocol. In this finding, low molecular weight 35 KDa PLC of $P$. aeruginosa was detected by Sonoki and Ikezawa (1975). On the other hand large size PLCs $76 \mathrm{KDa}$ (Berka and Vasil, 1982), 72-78 KDa (Titball, 
1993) and $70 \mathrm{KDa}$ (Lucchesi and Domenech, 1994) were detected in other $P$. aeruginosa strains.

TABLE 1. Purification profile of $P$. aeruginosa phospholipase C.

\begin{tabular}{|c|c|c|c|c|c|c|c|}
\hline $\begin{array}{c}\text { Purification } \\
\text { step }\end{array}$ & $\begin{array}{c}\text { Total } \\
\text { volume } \\
(\mathbf{m l})\end{array}$ & $\begin{array}{c}\text { Activity } \\
\left(\mathbf{U m l}^{-1}\right)\end{array}$ & $\begin{array}{c}\text { Protein } \\
\left(\mathbf{m g ~ m}^{-\mathbf{1}}\right)\end{array}$ & $\begin{array}{c}\text { Specific } \\
\text { activity U } \\
\mathbf{m g}^{-1} \\
\text { protein }\end{array}$ & $\begin{array}{c}\text { Purification } \\
\text { fold }\end{array}$ & Yield \% & $\begin{array}{c}\text { Hemolytic } \\
\text { activity } \\
\text { (mm) }\end{array}$ \\
\hline $\begin{array}{c}\text { Crude } \\
\text { enzyme }\end{array}$ & 750 & 10.5 & 0.55 & 19 & 1 & 100 & 0.7 \\
\hline $\begin{array}{c}\text { Amm. } \\
\text { Sulphate } \\
70 \%\end{array}$ & 35 & 15.5 & 0.48 & 32.3 & 1.7 & 6.9 & 1.5 \\
\hline $\begin{array}{c}\text { Sephadex } \\
\text { G100 }\end{array}$ & 50 & 44.2 & 0.375 & 118.7 & 6.2 & 28.2 & 2.5 \\
\hline
\end{tabular}

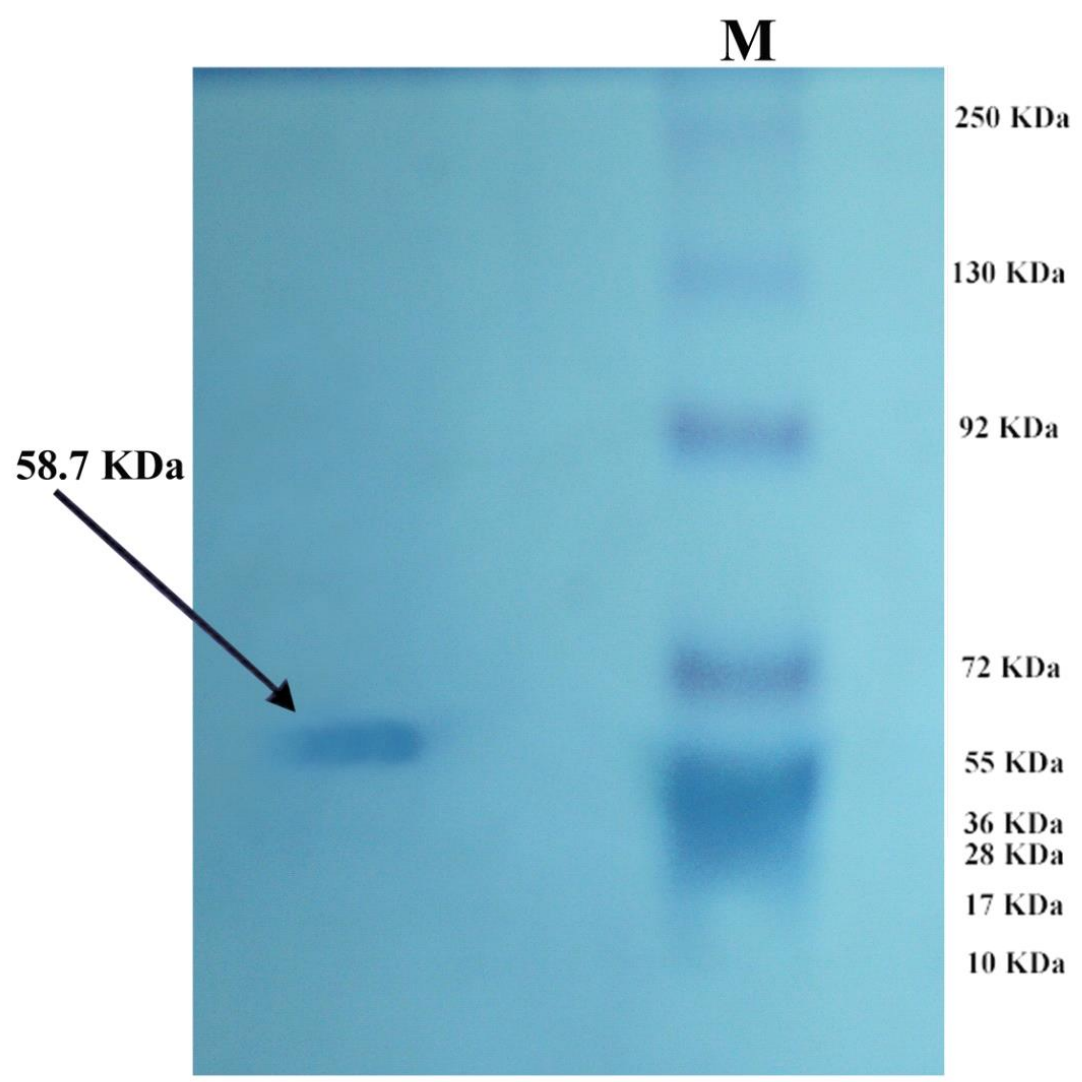

Fig. 1. Polyacrylamide gel electrophoresis( SDS-PAGE )of $P$. aeruginosa phospholipase $\mathrm{C}(\mathrm{M}=$ marker multicolor broad range protein ladder covering range from 10 to $250 \mathrm{kDa}$ ). 
Amino acids composition of $P$. aeruginosa

Moreover, the amino acid composition of $P$. aeruginosa PLC represented in (Table 2) revealed that alanine was the dominant amino acid $(13.1 \%)$ followed by leucine $(9.9 \%)$ and glycine $(8.3 \%)$. Alanine is known to play a role in substrate recognition or substrate specificity (Betts and Russell, 2003). Also, the results indicated that PLC under investigation was relatively rich in asp, arg and pro. Also, there was a predominance of the hydrophobic residues $(42.2 \%)$ that could explain the affinity of tested PLC to hydrophobic substances. While the data obtained by Berka and Vasil (1982) for the heat labile hemolysin PLC from $P$. aeruginosa indicated that the enzyme was rich in glycine, serine, threonine, asparlyt, aromatic amino acids, but was cystine free.

TABLE 2. Amino acids composition of $P$. aeruginosa phospholipase $C$.

\begin{tabular}{|c|c|}
\hline Amino acid & $\%$ \\
\hline Ala & 13.1 \\
\hline Cys & 0.2 \\
\hline Asp & 7.4 \\
\hline Glu & 4.4 \\
\hline Phe & 4.4 \\
\hline Gly & 8.3 \\
\hline His & 2.6 \\
\hline Ile & 2.6 \\
\hline Lys & 3.1 \\
\hline Leuc & 9.9 \\
\hline Met & 1.1 \\
\hline Asn & 4.1 \\
\hline Pro & 6.1 \\
\hline Gln & 5.2 \\
\hline Arg & 7.2 \\
\hline Ser & 4.8 \\
\hline Thr & 4.6 \\
\hline Val & 5.7 \\
\hline $\operatorname{Trp}$ & 1.8 \\
\hline Tyr & 3.4 \\
\hline & 100 \\
\hline
\end{tabular}

\section{Detection plcH gene}

The resulting DNA sequence of the putative plc contained $1.6 \mathrm{~kb}$ (Fig.2) was compared with the published sequences using the Basic Local Alignment Search Tool (BLAST) program (http://www.ncbi.nlm.nih.gov/blast), and investigated to homogeneity in the GenBank data base. The sequence of the eluted PCR product of $P$. aeruginosa was deposited in data base under accession number KC405580. The phylogenetic tree (Fig.3) constructed from the DNA alignment profile using Clustal W (http://www.ge Cnome.jp/tools/clustalw/) revealed that plc had maximum structural similarities with $P$. entomophila YP-606779.1 (100\%), $P$. chlororaphis ZP-10174580.1 (67\%), P. synxantha ZP-10143859.1 (68\%), P.

Egypt. J. Bot., 54, No. 1 (2014) 
fluorescens YP-006322361.1 (69\%), ABE73153.1 (68\%) , YP-002870511.1 (68\%), EIK63323.1 (68\%) and YP-346558.1 (62\%). Structurally, the higher similarities of our plc gene sequence with those from Pseudomonades, ensures the molecular and biochemical proximity with the tested P. aeruginosa. Also our result was matching with Viana-Niero et al. (2004) who assayed 1599, 1611, 1610 and 1478 bp fragments from four genes plc $A, B, C$ and $D$ respectively obtained from Mycobacterium tuberculosis. These plc genes had significant similarity with $P$. aeruginosa genes $p l c \mathrm{H}$ and $p l c \mathrm{~N}$ which encoded hemolytic and non-hemolytic PLC enzyme respectively. Simillarly $1.3 \mathrm{~kb} p l c \mathrm{~B}, 1.9 \mathrm{~kb} p l c \mathrm{H}$ and $1.7 \mathrm{~kb} p l c \mathrm{~N}$ genes were detected from $P$. aeruginosa $\mathrm{PAOl}$ by Liyama et al. (2008).

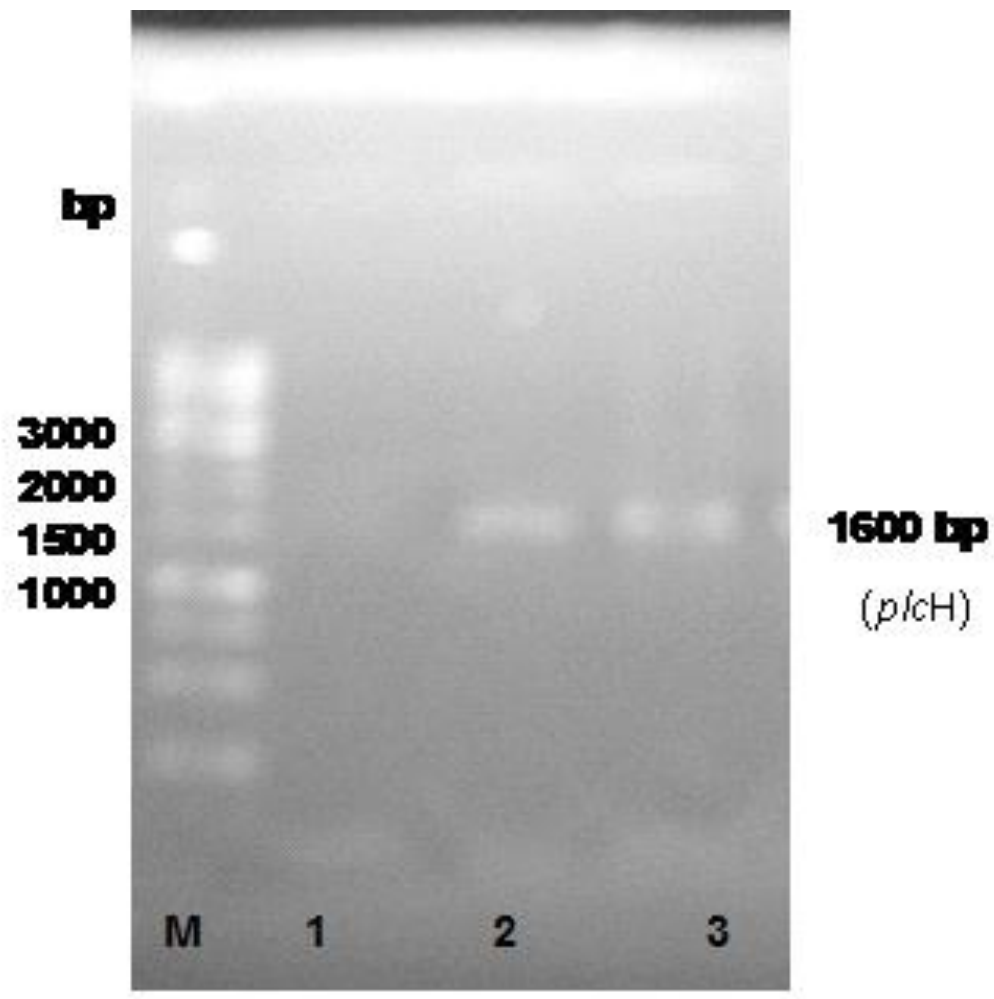

Fig. 2 . Electrophoretic pattern showing PCR (1\% agaros gel ). Lanes 1 to 3 (where: $1=$ negative control (without DNA), 2and3 $=$ DNA isolated from $P$. aeruginose), M: GeneRuler $1 \mathrm{~Kb}$ ladder DNA Marker $(10,8,6,5,3.5,3$, $2.5,2,1.5,1,0.75,0.5,0.25 \mathrm{~kb}$, it contains three reference bands of 6,3 and 1 kb) for easy orientation. 


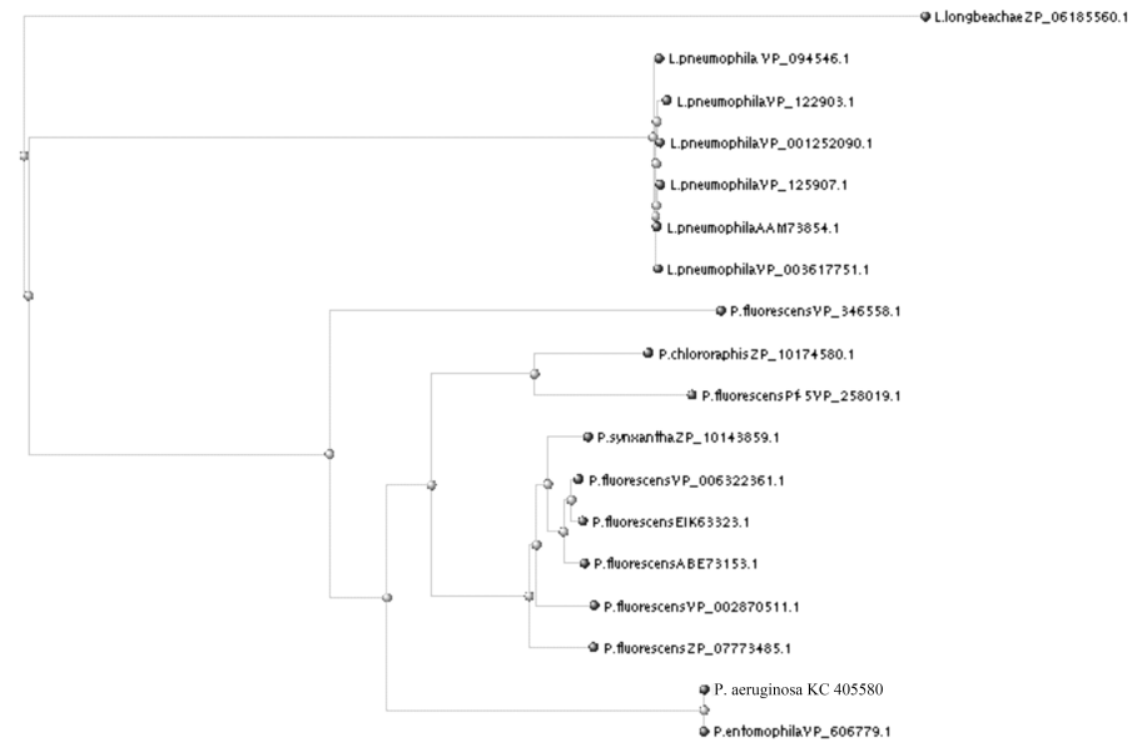

Fig. 3. Phylogenetic tree of $p l c \mathrm{H}$ gene encoded the putative $P$. aurginosa protein with the corresponding gene from the data base using Clustal W software.

Kinetics and biochemical properties of $P$. aeruginosa PLC

Concerning the biochemical properties of the purified PLC, a linear relation between the relative activity and reaction time of PLC at different temperatures $(25,35,45,55$ and65C ) was observed in (Fig. 4). It was found that, PLC under investigation was expected to be inactivated above 65C. Regarding thermal kinetic parameters, thermal inactivation rate $(\mathrm{Kr})$ and half-life lime $\left(\mathrm{T}_{1 / 2}\right)$ decreased as temperature increased and the recorded half-life temperature $\mathrm{Tm}$ was 42C (Table 3). Concerning this finding, Fujita (1987) stated that, $P$. aeruginosa produced at least two hemolysins, a heat-labile which is known as phospholipase $\mathrm{C}$ and heat stable glycolipid. This feature was significantly distinct for other Pseudomonas PLCs (Sugimori and Nakamura, 2006).

Purified P. aeruginosa PLC showed a wide range of $\mathrm{pH}$ stability. Data represented graphically in (Fig. 5) showed that, the enzyme activity was approximately stable between $\mathrm{pH} 8.5$ to 10 and the activity significantly decreased below and above it. In similar manner Wang et al. (2010) found that, the PLC of B. mycoides 970 was stable at $\mathrm{pH}$ 5-9.5. Extremely decrease or increase in $\mathrm{pH}$ altered three dimensional protein structure causing denaturaion and inactivation of enzyme (D'Souza et al., 1987).

In the present investigation, (Table 4) indicates that, the pure PLC of tested $P$. aeruginosa was activated by the divalent ions $\mathrm{Zn}^{2+}, \mathrm{Ca}^{2+}, \mathrm{Ba}^{+2}$ and $\mathrm{Co}^{2+}$ in descending order while $\mathrm{Mn}^{2+}, \mathrm{Cu}^{2+}$ and $\mathrm{Fe}^{2+}$ completely inhibited the enzyme activity. In partial coincidence with our results, Moreau et al. (1988) reported that, $\mathrm{Ca}^{2+}$ and $\mathrm{Zn}^{2+}$ ions were found to play a specific role in hydrolysis of PC by Egypt. J. Bot., 54, No. 1 (2014) 
Cl. perfringens. $\mathrm{Ca}^{2+}$ is essential for enzyme binding to lipid film, whereas $\mathrm{Zn}^{2+}$ was especially involved in the catalytic hydrolysis of the substrate. Also, Titball (1993) denoted that, $\mathrm{Zn}^{2+}$ was absolutely necessary for catalytic function of several bacterial enzymes while $\mathrm{Ca}^{2+}$ and $\mathrm{Mg}^{2+}$ were reported to significantly influence activity of bacterial PLCs molecules. It was also noticed that, the studied enzyme activity in presence of $\mathrm{Zn}^{2+}$ ions increased by 1.19 fold and significantly decreased by 1 or $5 \mathrm{mM}$ EDTA. Also the enzyme restored its activity when $\mathrm{Zn}^{2+}$ ions were added in presence of $1 \mathrm{mM}$ EDTA. This results collectively suggested that the $P$. aeruginosa PLC may be a metallophospholipase $\mathrm{C}$ containing $\mathrm{Zn}^{2+}$ ions in its active site. Crevel et al. (1994) reported that, not only Gram positive but also Gram negative $P$. fluorescence produced $\mathrm{Zn}^{2+}$ metallophospholipase C. Moreover PLC of $B$. mycoides was characterized as a metallophospholipase and $\mathrm{Zn}^{2+} \mathrm{Ca}^{2+}$, and $\mathrm{Ba}^{2+}$ were enzyme activators (Wang et al., 2010). Some $\mathrm{Zn}^{2+}$-PLCs, like the -toxin of Cl. perfringens are potent toxins and have roles in its pathogenesity.

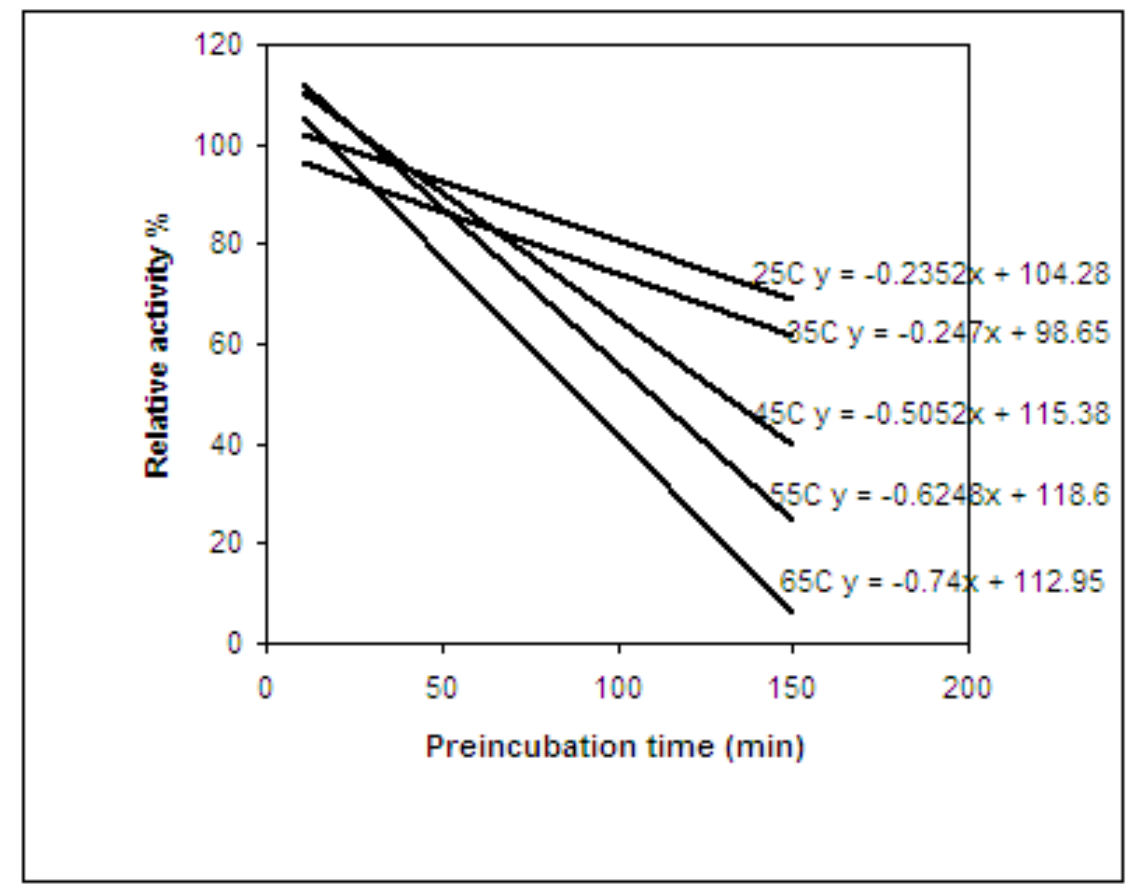

Fig. 4 .Thermal stability of $P$. aeruginosa phospholipase C . 
TABLE 3. Thermal inactivation parameters of $P$. aeruginosa phospholipase C.

\begin{tabular}{|c|c|c|c|}
\hline Temp. (C) & $\mathbf{T}^{1} / \mathbf{2}(\min )^{*}$ & $\operatorname{Kr} S^{-1 * *}$ & $\mathbf{T m}^{* * * *}(\mathbf{C})$ \\
\hline 25 & 266.3 & 0.13 & \multirow{5}{*}{42} \\
\hline 35 & 230.7 & 0.146 & \\
\hline 45 & 198.0 & 0.163 & \\
\hline 55 & 129.5 & 0.31 & \\
\hline 65 & 109.7 & 0.38 & \\
\hline
\end{tabular}

* Half-life times $\left(\mathrm{T}^{1 / 2} / 2\right)$ expressed by minutes

** Thermal inactivation rate $(\mathrm{Kr})$ expressed per seconds

*** Half-life temperature (Tm) expressed by $\mathrm{C}$

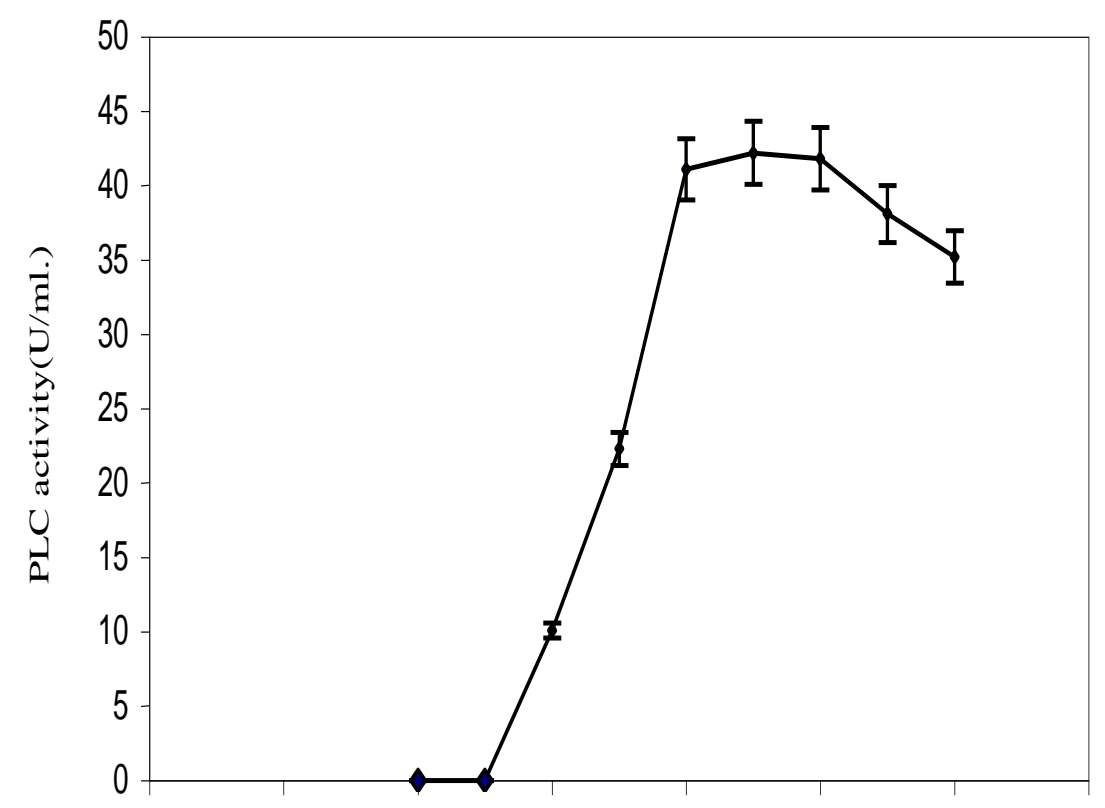

Fig . 5. PH stability of P.aeruginosa phospholipase C.

Egypt. J. Bot., 54, No. 1 (2014) 
TABLE 4.Effect of metal ions on $P$ aeruginosa phospholipase C activity.

\begin{tabular}{|l|c|c|}
\hline \multicolumn{1}{|c|}{ Metal ion } & $\begin{array}{c}\text { Concentration } \\
((\mathbf{m M}\end{array}$ & Relative activity \\
\hline Control & - & $\mathrm{e} 100$ \\
\hline${ }^{+} \mathrm{Mn}^{2}$ & 5 & - \\
\hline${ }^{+} \mathrm{Mg}^{2}$ & 5 & $\mathrm{e} 100$ \\
\hline${ }^{+} \mathrm{Ba}^{2}$ & 5 & $\mathrm{c} 107$ \\
\hline${ }^{+} \mathrm{Zn}^{2}$ & 5 & $\mathrm{a} 119$ \\
\hline${ }^{+} \mathrm{Co}^{2}$ & 5 & $\mathrm{~d} 103$ \\
\hline${ }^{+} \mathrm{Cu}^{2}$ & 5 & - \\
\hline${ }^{+} \mathrm{Fe}^{2}$ & 5 & - \\
\hline${ }^{+} \mathrm{Ca}^{2}$ & 5 & $\mathrm{~b} 112$ \\
\hline EDTA & 1 & $\mathrm{f} 57.3$ \\
\hline EDTA & 5 & $\mathrm{~g} 26.4$ \\
\hline EDTA $+\mathrm{Zn}^{2+}$ & $1+5$ & $\mathrm{~b} 112$ \\
\hline L.S.D & & 1.62 \\
\hline
\end{tabular}

Values with different letters within the same column differ significantly at p0.01 >

From the linear relation between PC concentration (M) and PLC activity (Fig. 6) it was found that, the Vmax, $\mathrm{km}$ and Kcat for tested PLC were $1.88 \mathrm{U}$ $\mathrm{mg}^{-1} \mathrm{~min}^{-1}, 0.12 \mathrm{uM}$ and $3.2 \times 10^{-5} \mathrm{~S}^{-1}$ respectively. Affinity of PLC for PC as a substrate was detected by Berka and Vasil (1982), Lucchesi and Domenech (1994) and Ibarguren et al. (2010) for different P. aeruginosa strains. Wehbi et al. (2003) explained the activation of PLC and Pi cleavage from phosphatidylinositol by increasing the Kcat and decreasing the $\mathrm{km}$ of the enzyme. Also, the small $\mathrm{km}$ $(0.12 \mathrm{M})$ of the tested PLC indicated high affinity of the enzyme to substrate, approaching Vmax more quickly (Lehninger et al., 2005).

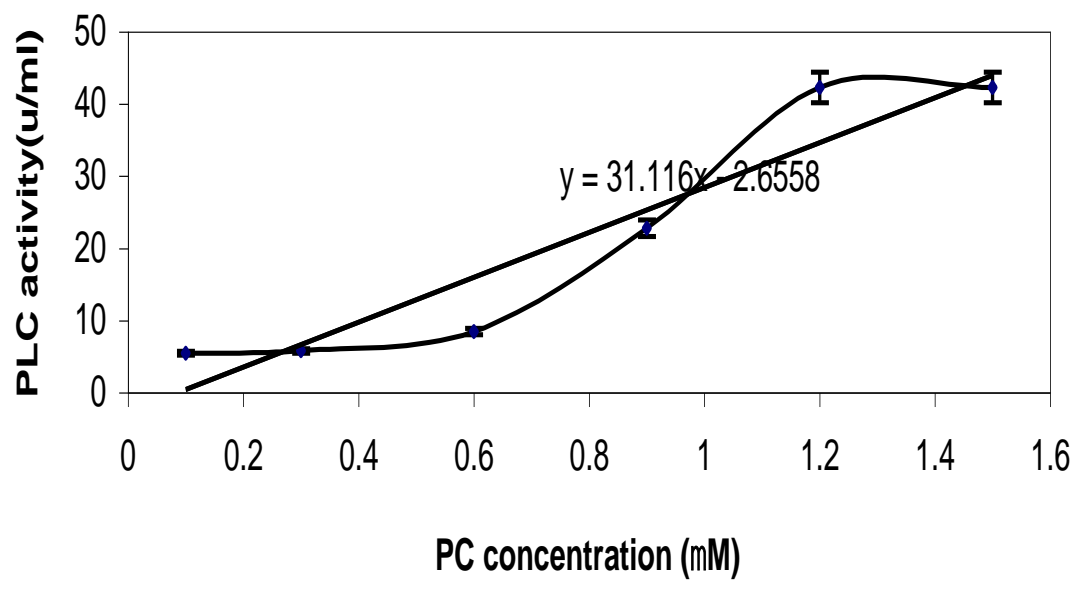

Fig . 6. Effect of different PC concentration on p. aeruginosa phospholipase $\mathrm{C}$ activity. 
Hemolytic and mice lethal activities of fresh and heat detoxified P. aeruginosa PLC

Studying the hemolytic and mice lethal activities of the normal and heat detoxified $P$. aeruginosa PLC were attained through this work as shown in (Table 5). Hemolytic activity of purified PLC from P. aeruginosa was described previously by Meyers et al. (1992); Flieger et al. (2000); Gomez et al. (2001); Son et al. (2007) and Kida et al. (2011). In present study injection into mice via 64(HU/ml.) hemolytic titer of fresh or heat detoxified ( at $65 \mathrm{C}$ for $30 \mathrm{~min}$.) $P$. aeruginosa PLC was associated by 100 and $25 \%$ mortality after $12 \mathrm{hr}$ respectively . The same percentages were obtained after $24 \mathrm{hr}$ when mice were injected by half hemolytic titer (128) of fresh and heated (at $100 \mathrm{C}$ for $30 \mathrm{~min}$ ) P. aeruginosa PS11 hemolysin respectively (Khalil, 2009). This assumes that, the mortality of experimental animals was attributed to an immunological shock induced by the high dose of cytotoxic PLCH (Meyers et al., 1992 and Wargo et al., 2011).

TABLE 5. Lethal activity of fresh and heat detoxified $P$. aeruginosa phospholipase C on mice.

\begin{tabular}{|l|c|c|c|}
\hline \multicolumn{2}{|c|}{ PLC } & $\begin{array}{r}\text { hemolytic } \\
\left.\text { titer(HU } \mathbf{~ m}^{-1}\right)\end{array}$ & Mice mortality \% \\
\hline \multirow{2}{|c|}{ control } & $64 \mathrm{a}$ & $100 \mathrm{a}$ \\
\hline \multirow{3}{*}{$\begin{array}{c}\text { Heat } \\
\text { detoxified at } \\
65 \mathrm{C}\end{array}$} & $30 \mathrm{~min}$ & $64 \mathrm{a}$ & $25 \mathrm{~b}$ \\
\cline { 2 - 4 } & $60 \mathrm{~min}$ & $32 \mathrm{~b}$ & $0 \mathrm{c}$ \\
\cline { 2 - 4 } & $90 \mathrm{~min}$ & $0 \mathrm{c}$ & $0 \mathrm{c}$ \\
\hline & L.S.D & 25.6 & 11.35 \\
\hline
\end{tabular}

Values with different letters within the same column differ significantly at $p<0.01$

Also in the present study PLC maintained $32 \mathrm{HU} / \mathrm{ml}$ hemolytic titer was completely lost its lethal activity on mice after $60 \mathrm{~min}$ at $65 \mathrm{C}$. This assumed that, low doses of heat detoxified PLC enhanced the immune response to more mice protection as recorded by Manohar et al. (1966) and Khalil (2009).

In vivo, immunological characteristics and cytotoxicity of $P$. aeruginosa PLC in rabbits

Antigenicity of fresh and heat detoxified (65C for 60 min.) PLC in New Zealand rabbits was evaluated by measuring the increase in the plasma immunoglobulin IgG antibodies as compared to control. From the profile of the plasma IgG concentrations (Fig.7,a\&b), the titer of IgG appeared clearly after 15 days of the last injection dose of fresh and detoxified enzyme by about 1.15 and 1.21 fold respectively higher compared to the control (without enzyme), followed by the decrease in the titer of $\mathrm{IgG}$ up to 45 days. Results for antigenic properties of tested PLC especially for induction of $\mathrm{IgG}$ antibodies after 2 weeks was consistent with those reported for $P$. aeruginosa PLC in mice model of Preston et al. (1991). Also Adhikari et al. (2012) reported that vaccinated mice showed higher ELISA and neutralizining antibody titer, this finding was Egypt. J. Bot., 54, No. 1 (2014) 
consistent with the ability of antibodies to neutralize Staphylococcus aureus hemolysin (HLa) via inhibition of Hla oligomerization. On the other hand the lowering in titer of anti-PLC antibodies during the circulating time after 2 weeks assumed that these antibodies became incapable of neutralizing fresh or detoxified PLC activity in situ and don't affect the enzymatic function. It was expected that, antibodies don't bind to, or are incapable of conformational modification of the active site (Chin and Watts, 1988).
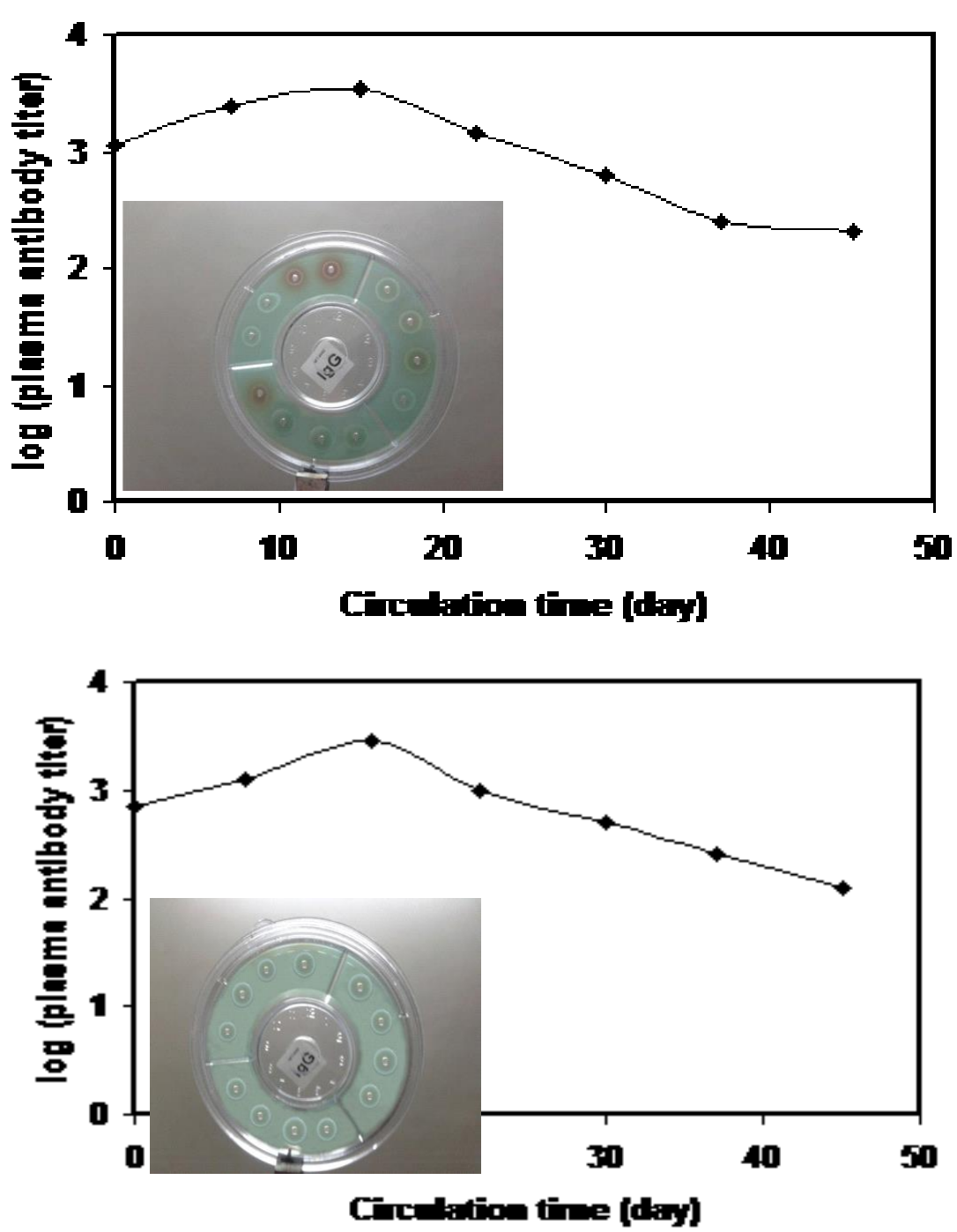

Fig. 7. Plasma anti-PLC antibody titer (IgG) in New Zealand Rabbits injected with fresh (a) and heat detoxified (b) $P$. aeruginose phospholipase $C$. 
Hematological and blood chemistry picture for the New Zealand rabbits in response to administration of fresh and detoxified $P$. aeruginosa PLC were evaluated in (Table 5). It was found that the significant change in all hematological parameters (RBCs, WBCs and hemoglobin) of rabbits injected with fresh PLC during 45 days, that the enzyme recognized phospholipids found predominantly on eukaryotic cells membrane (Terada, 1999) and leys red blood cells (Tami, 2008) with release of hem into the surrounding (Sritharan, 2007). Also the observed dysfunction in liver and kidney chemistry explained that the primary target organs involved in hemolytic PLC induced toxicity in the liver and kidney (Meyers et al., 1992).On the other hand there was no obvious changes in blood hematology and chemistry of rabbits injected with detoxified $P$. aeruginosa PLC. The increase in total leukocyte after treatment with low dose of heated PLC indicated that leukocyte specially granulocytes play a major role in control of P.aeruginosa infections (Terada, 1999). These results attracted attention to PLC vast importance to the enhancement of the immune response to more protection against bacterial infection using different routes of immunization with heat inactivated bacterial PLC (Manohar et al, 1966 Estahbanati et al., 2002 , Ipaktchi et al., 2007 and Khalil 2009) .

\section{Conclusion}

The data obtained throughout this study indicated that, the hemolytic PLC was purified to homogeneity from culture of $P$. aeruginosa 1589741 strain. The enzyme revealed its characteristic properties in relation to other bacterial PLC. Moreover, thermal, $\mathrm{pH}$ stability, ions effect and substrate kinetics illustrated the relation between biochemical properties of the enzyme and its activity. Also the results suggested that, hemolytic PLC contributed to in vivo virulence of $P$. aruginosa.The data obtained about mice protection and rabbits immunogenicity by heat detoxified PLC indicated that this toxin may represented a prime candidate for vaccine development in future works in the immunotherapy application against certain pathogenic bacteria.

Acknowledgement: I greatly thank my colleagues in Molecular Biology Lab., Botany Department, Faculty of Science, Zagzig University, for their valuable guidance for the molecular processing of enzyme.

Egypt. J. Bot., 54, No. 1 (2014) 
CHARACTERIZATION AND IMMUNOLOGICAL...

TABLE 6. Cytoyoxicity of normal and heat detoxified (65 $\mathrm{C}$ for $60 \mathrm{~min}$.) hemolytic $P$. aeruginosa phospholipase $\mathrm{C}$ on rabbits.

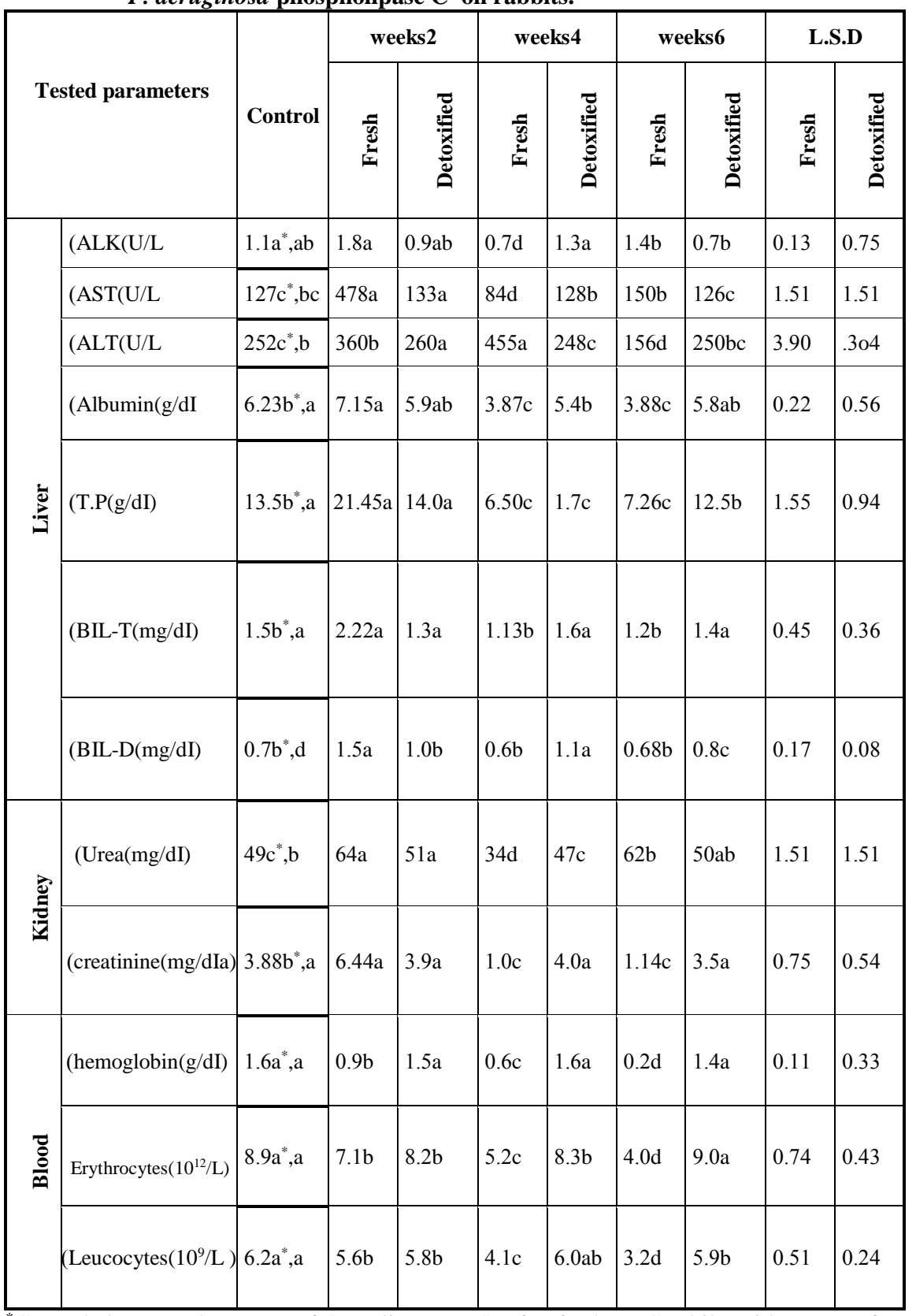

*Control data are the mean of 3 replicates \pm SE for fresh PLC while without star for detoxified PLC. Values with different letters within the same column differ significantly at $\mathrm{p}<0.01$ 


\section{References}

Abraham, E. (1992) Intranasal immunization with bacterial polysaccharide containing liposomes enhances antigen-specific pulmonary secretory antibody response. Vaccine, 10 (7), 461-468.

Adhikari, R.P.; Karauzum, H. and Sawa, j. et al. (2012) Noval structurally ddesigned vaccine for $\mathrm{S}$. aureus $\alpha$ - hemolysin : Pritection against bacteremic and pneumonia . PLoS One .www.plosone org. 7 (6),1-11.

Altschul, S.F., Madden, T.L., Schaffer, A.A., Zhang, J., Zhang, Z., Miller, W. and Lipman, D.J. (1997) Gapped BLAST and PSI-BLAST: a new generation of protein database search programs. Nucleic Acids Res., 17, 3289-402.

Berk, R.S. (1964) Partial purification of the extracellular hemolysin of Pseudomonas aeruginosa. J. Bacteriol., 88 (3), 559-565.

Berka, R. and Vasil, M. (1982) Phospholipase C (heat-labile hemolysin) of Pseudomonas aeruginosa: Purification and preliminary characterization. J. Bacteriol., $152(1), 229-245$

Betts, M. and Russell, R. (2003) Amino acid properties and consequences of substitutions. "Bioinformatics for Geneticists", M.R. Barnes, I.C. Gray (Ed.), Wiley.

Chin, J.C. and Watts, J.E. (1988) Biological properties of phospholipase C purified from a fleeceropt isolate of Pseudomonas aeruginosa. J. General. Microbiol., 134, 2567-2575.

Crevel, I., Sally, U., Carne, A. and Katan, M. (1994) Purification and properties of Zinc. Metallophospholipase C from Pseudomonas fluorescens. Eur. J. Biochem., 224 (3), 845-852.

D'Souza, V.T., Lu, X.L., Ginger, R.D. and Bender, M.L. (1987) Thermal and pH stability of B. benzyme. Proc. Natl. Acad. Sci. USA, 84, 673-674.

Elleboudy, N.S., Aboulwafa, M.M. and Hassouna, N.a. (2011) Characterization of phospholipase C productivity by Pseudomonas aeruginosa, Bacillus cereus and Staphylococcus aereus isolates. J. American Sci., 7 (8), 545-566.

Estahbanati, H.K., Kashani, P.P. and Ghanaatpisheh, F. (2002) Frequency of Pseudomonas aeruginosa serotypes in burn word infections and their resistance to antibiotics. Burns, 28 (4), 340-348.

Flieger, A., Gong, S., Falige, M. and Neumeister, B. (2000) Critical evaluation of P. nitrophenylphosphorylcholine $(P$-NPPC) as artificial substrate for the detection of phospholipase C. Enzyme Microb. Technol., 26, 451-458.

Fujita, K. (1987) Heat-stable hemolysin of Pseudomonas aeruginosa. Hokkaido Lgaku Zasshi, 62 (3) , 392-401. 
Gomez, A., Mve-Obiang, A., Vray, B., Rudnicka, W., Shamputa, I., Portaels, F., Meyers, W., Fonteyne, P. and Realini, L. (2001): Detection of phospholipase C in nontuberculous Mycobacteria and its possible in hemolytic activity. J. CLin. Microbiol., 39, 1396-1401.

Hassanein, W. (2009) Molecular identification of antibiotic resistant Pseudomonas aeruginosa Wt. Aust. J. Basic Appl. Sci., 3 (3), 2144-2153.

Ibarguren, M., Bomans, P., Frederik, P., Stonechouse, M., Vasil, M., Alonso, A. and Goni, F. (2010) End-products diarylglycerol and ceramide modulate membrane fusion induced by phospholipase C/sphingomyelinase from Pseudomonas aeruginosa. Biochem. Biophys. Acta., 1798 (1), 59-64

Ipaktchi, K., Matter, A., Niederbichler, A., Hoesel, L., Vollmannshauser, S., Hemmila, M., Minter, R., Su, G., Wang, S. and Arbabi, S. (2007) Topical p38 MAPK inhibition reduces bacterial growth in an in vivo burn wond model. Surgery, 142 (1), 86-93.

Johnson, M.K. and Boese-Marrazzo, D. (1980) Production and properties of heat-stable extracellular hemolysin from Pseudomonas aeruginosa. Infect. and Immun., 29 (3), 1028-1033.

Kates, M. (1972): In: “Techniques in Lipidology". Laboratory techniques in biochemistry and molecular biology work T.S and Work E (Ed.), Nerth Holland American Elseiver, London, New York.

Khalil, M.A. (2009) Studies on the control of some hemolytic bacteria. Ph.D. Thesis, Botany Department, Faculty of Science, Tanta University.

Kida, Y., Shimizu, T. and Kuwano, K. (2011) Cooperation between LepA and plcH contributes to the in vivo virulence and growth of Pseudominas aeruginosa in mice. Infect. Immun., 79, 211-219.

Kurioka, S. and Liu, P.V. (1967) Improved assay method for phospholipase C. Appl. Microb., 15 (3), 551-555.

Laemmli, V.K. (1970) Cleavage of structural proteins during the assembly of the head of bacteriophage T4. Nature (London), 227, 680-685.

Lehninger, A.L., Nelson, D.L. and Cox, M.M. (2005) "Lehninger Principles of Biochemistry”. $4^{\text {th }}$ ed., New York, W.H. Freeman and Company, 194-196. ISBN 9780-7167-4339-2.

Liyama, K., Chieda, Y., Lee, J.M., Kusakabe, T., Yasungaa-Aoki, C. And Shimizu, S. (2008) Virulence of phospholipase C mutants of Pseudomonas aeruginosa PAO: against the sikworm, Bomby Xmori J. of Insect Biotechnol. and Seriol., 77, 115-120.

Lowry, O.H., Rosebrough, N.J., Farr, A.L. and Randall, R.J. (1951) Protein measurements with the Folin phenol reagent. J. Biol. Chem., 193, 265-275. 
Lucchesi, G.L. and Domenech, C.E. (1994) A simple and reliable method for the purification of Pseudomona aeruginosa phospholipase C produced in a high phosphate medium containing choline. Internat. J. of Biochem., 26 (2), 155-162.

Magalhaes, C.A., Rossato, S.S., Barbosa, A.S., doSontas, T.O., Elias, W.P., Sicrili, M.P. and Piazza, R. (2011) The ability of haemolysins expressed by atypical enteropathogenic Escherichia coli to bind to extracellular matrix components. Men. Inst. Oswaldo Cruz Riode Janeiro, 106 (2), 146-152.

Manohar, M., Kumar S. and Lindorfer R.K.(1966) Heat reactivation of the $\alpha$ hemolytic, dermonecrotic, and lethal activities of crude and purified staphylococcal $\alpha$ toxin. J. Bacteriol., 91(5),1681-1685.

Meyers, J., Palmer, C.K., Bale, L.A., Kernacki, K., Preston, M., Brown, T. and Berk, R.S. (1992) In vivo and in vitro toxicity of phospholipase C from Pseudomonas aeruginosa. Toxicon, 30 (2), 161-169.

Moreau, H., Piperoni, G., Jolivet-Reynaud, C., Alouf, J. and Vergr, R. (1988) A new kinetic approach for studying phospholipase C (clostridum perfringens \& toxin) activity on phospholipids monolayers. Biochemistry, 27, 2319-2323.

Mukry, S.N., Ahmad, A. and Khan, S.A. (2010) Screening and partial characterization of hemolysins from Bacillus sp.: Strain S128 and S144 are hemolysin B (HBL) producers. Park. J. Bot., 42 (1), 463-472.

Ostroff, R. and Vasil, M.L. (1987) Identification of a new phospholipase C activity by analysis of an insertional mutation in the hemolytic phospholipase $\mathrm{C}$ structural gene of Pseudomonas aeruginosa. J of Bacteriol., 169 (10), 4597-4601.

Preston, M.J., berk, J.M., Hazlett, L.D> and Berk, R.S. (1991) Serum antibody response to Pseudomonas aeruginosa antigens during corneal infection. Infect. Immun., 59 (6), 1984-1990.

Salvatore, D. and Reagle, D. (2001) Theory and Problems of Statistics and Econometrics. $2^{\text {nd }}$ ed., McGraw Hill, New York.

Sambrook, J. and Russel, D. (2001) "Molecular cloning: A laboratory Manual", $3^{\text {rd }}$ ed., Cold Springs Harbour Press.

Schmiel, D.H. and Miller, V.L. (1999) Bacterial phospholipases and pathogenesis. Microbes. Infect., 1, 1103-1112.

Son, M.S., Mathews, W.J., Jr. Kang, Y., Nguyen, D.T. and Hoang, T.T. (2007) In vivo evidence of Pseudomonas aeruginosa nutrient acquisition and pathogenesis in the lungs of cystic fibrosis patients. Infect. Immun., 75, 5313-58324.

Sonoki, S. and Ikezawa, H. (1975) Studies on phospholipase C from Pseudomonas aeruginosa: Purification and some properties of phospholipase C. Biochemica et Biophysica Acta (BBA). Enzymology, 403 (2), 412-424. 
Stonehous, M.J., Cota-Gomez, A., Parker, S.K., Martin, W.E., Hankin, J.A., Murphy, R.C., Chen, W., Lim, K.B., Hachett, M. and other authers (2002) A novel class of microbial phosphocholine-specific phospholipases C. Mol. Microbiol., 46, 661-676.

Stritharan, M. (2007) Iron and bacterial virulence. Ind. J. Med. Microbiol., 24, 163-164.

Sugimori, D. and Nakamura, M. (2006) Partial purification and some properties of phospholipase C from Pseudomonas sp. Strain K53.2. Biosci. Biotechnol. Biochem., 70, 535-537.

Tami, P. (2008) Blood agar (BAP) Bacterial growth medium, differential medium to identify -hemoplytic Streptoccoccus. Sci. Nat. Microbiol., 10, 12-15.

Terada, L.S.; Johansen, K.A.; Nowbar, S.; Vasil, A.I. and Vasil, M.L. (1999) Pseudomonas aeruginosa hemolytic phospholipase C suppresses neutrophil respiratory burset activity Infect.Immun., 67, 2371-2376

Titball, R.W. (1993) Bacterial phospholipase C. Microbiol. Rev., 57, 347-366.

Titball, R.W. (1998) Bacterial phospholipases. symp. ser. soc. Appl. Microbiol., 27, 12751375.

Tous, G.T. ,Fausnaugh, J.L., Akinyosoye, O., Ioskland, H., Winter Cash, P.,Vitorico, F.J. and Stein, S.(1989) Amino acid analysis on polyvinylidene difluoride membranes. Anal.Biochem.,179, 50-55.

Viana-Niero, C., Deltas, P.E., Van Soolingen, D. and Leao, S.C. (2004) Analysis of genetic polymorphisms affecting the four phospholipase $\mathrm{C}(p l c)$ genes in Mycobacterium tuberculosis complex clinical isolates. Microbiol., 150, 967-978.

Wang, C.G., Chen, M.K. and Chen, T. (2010) Improved purification and some properties of a novel phospholipase $\mathrm{C}$ from Bacillus mycoides strains 970. Afr, J. Microbiol. Res., 4 (7), 523-526.

Wargo, M., Ho, T.C., gross, M.J., Whittaker, L.A. and Hogan, P.A. (2009) GbdR regulates Pseudomonas aeruginosa $p l c \mathrm{H}$ and $p c h \mathrm{P}$ transcription in response to choline catabolites. Infect. Immun., 77, 1103-1111.

Wargo, M.; Gross, M.; Rajamani S.; allad, J.; Lundblad, L.; Allen, G.; Vasil, M.; Lectair, L. and Hogan, D. (2011) Hemolytic phospholipse C inhibition protects lung function during Pseudomons aeruginosa injection. Amr. J. Respir. Crit. Cae. Med, 184, 345-354.

Wehbi, H., Feng, J., Kolbeck, J., Ananthanarayanan, B., Cho, W. and Roberts, M. (2003) Investigating the interfacial binding of bacterial phosphatidylinositol-specific phospholipse C. Biochemistry, 42, 9374-9382.

Whitaker, J.R. (1972) In: "Principles of Enzymology for Food Sciences". Enzyme inhibitors pp. 255-282 New York: Marcel Dekker. 


\title{
الخصائص والصفات المناعية لإتزيم الفوسفرلبلز س المحل للام

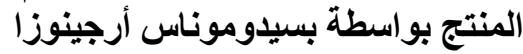

\author{
وسام عبد الغنى على حسانين \\ قسم النبات - كلية العلوم - جامعة الزقازيق الفين - مصر .
}

\begin{abstract}
تم انتاج إنزيم الفوسفوليبيز س بعد أربعة أيام من مزرعة لسلالة بسيدوموناس

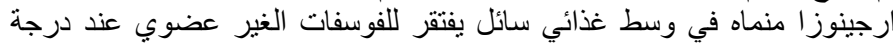

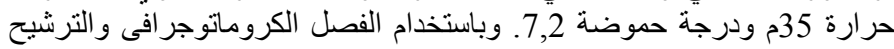

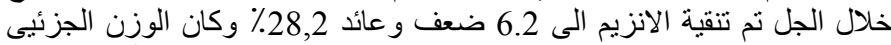

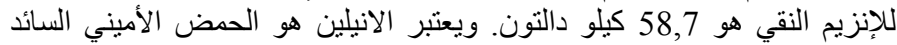

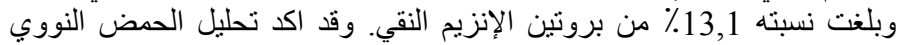

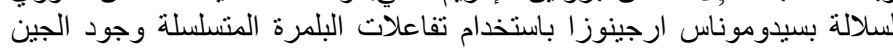

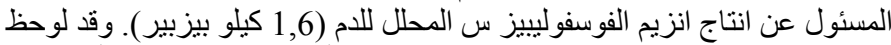

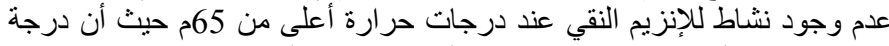

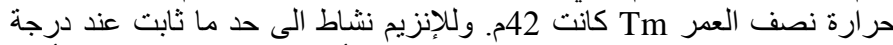

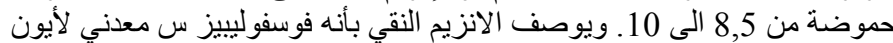

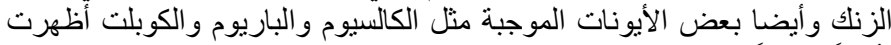

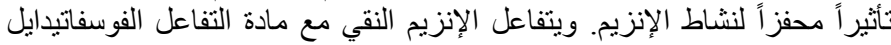

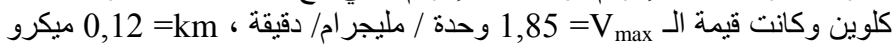

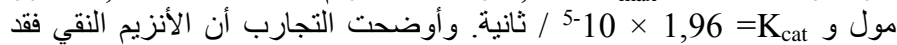

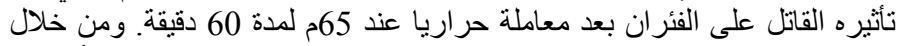

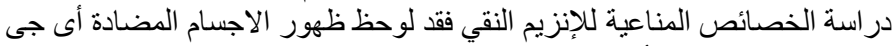

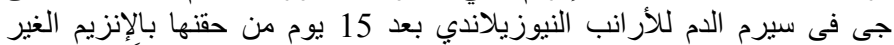

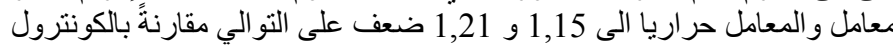

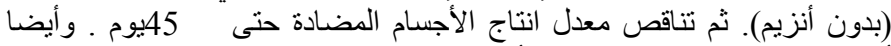

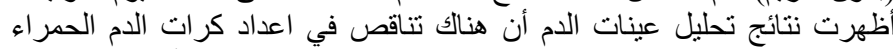

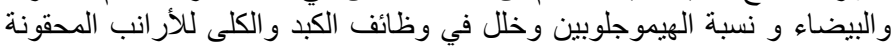
بالإنزيم الغير معامل حر اريا على العكس في في حالة الانزيم المعامل حر اريا.
\end{abstract}

